\title{
The Development of Yogyakarta Special Batik Design to Meet Customer Desire and Satisfaction Using Quality Function Deployment
}

\author{
Fauziyah $^{1 *}$ \\ ${ }^{1}$ Department of Management, Universitas Muhammadiyah Yogyakarta, Yogyakarta, Indonesia \\ *Corresponding author. Email: Fauziyah@umy.ac.id
}

\begin{abstract}
Small and Medium Enterprises (SMEs) are industrial sectors that play an essential role in supporting the Indonesian economy. SMEs hold a strategic role in the economic, social, and political fields because of its contribution to gross national product (GNP) and reducing unemployment. The SME sector that has grown rapidly in the last decade is batik. Almost all provinces in Indonesia have batik with their characteristics. Batik has a varied and unique design. High innovation and creativity support this design, making the batik industry more existent and developed. In this case, Yogyakarta is the center of the batik industry, which is growing rapidly, especially in terms of batik design. Consumers have many choices according to their character and taste. However, to better understand the design desired by consumers, it is necessary to conduct research related to the development of batik designs. The purpose of this study was to analyze the development of a special Yogyakarta batik design to fulfill customer desires and satisfaction by using Quality Function Deployment (QFD). The QFD method can be used to identify consumer desires, which will ultimately impact customer satisfaction. According to the manufacturer, based on the relationship between technical responses, the design improvement priorities included color selection, innovative design, and classical design. It deals with many other technical responses, meaning that the improvement of these three means also increases other technical response preferences.
\end{abstract}

Keywords: Batik Design, Quality Function Deployment, House of Quality.

\section{INTRODUCTION}

Small and Medium Enterprises (SMEs) have a significant role in advancing the Indonesian economy. Besides, as one alternative new job that can reduce unemployment, SMEs also play a role in encouraging economic growth after the 1997 monetary crisis. At that time, large companies experienced difficulties in developing their businesses. Currently, SMEs contribute significantly to regional income and Indonesia's national income [1].

SMEs' rapid growth must be recognized as a strategic and essential force to accelerate regional development every year. It is supported by government and banking programs that encourage new businesses. Also, the existence of revolution 4.0 increasingly encourages SMEs' rapid growth due to various facilities that can be obtained in terms of communication and information dissemination to develop their business throughout the world.
Batik is one of the fastest-growing industries in the last decade. Almost all provinces in Indonesia have batik with their characteristics. Batik has a varied and unique design. High innovation and creativity support this design, making the batik industry more existent and developed. Besides, revolution 4.0 enables connectivity in all fields, including the creative economy. In this case, Yogyakarta is the center of the batik industry, which is growing rapidly, especially in terms of batik design. The designs of batik range from classic batik, which is traditionally processed, to innovative contemporary batik. Consumers have many choices according to their character and taste. However, to better understand consumers' design, it is necessary to conduct research related to the development of batik designs that meet consumer desires.

The development of batik motif design is one of the efforts to strengthen the Indonesian creative industry's identity and excellence and preserve batik as a national 
cultural heritage. The art of batik is the local wisdom of the Indonesian people that reflects respect for nature. Batik is synonymous with Javanese culture. However, in reality, there are various unique batik patterns from various archipelago parts, for example, in Madura, Bali [1]. The art of batik on cloth in each region has a distinctive style that is a wealth of Indonesian culture.

Nevertheless, competition in the Batik industry is increasingly apparent because of the emergence of new batik entrepreneurs in this business line. Every business must have advantages and the right strategies to win the competition. Awareness of customers' importance in business sustainability needs to be considered a strategy inherent in this business. Besides, the product or service's quality is essential to determine which company's products or services can compete in the market [3]. Also, it requires a batik design that suits its customers' tastes and expectations to win the batik industry competition.

This paper presents an analysis of the considerations used in Batik design development, using the quality function deployment (QFD) as the link to customer requirements. Quality Function Deployment (QFD) is a cross-functional planning tool utilized to ensure that the customer's voice is deployed throughout the product planning and design stages. QFD is used to encourage breakthrough thinking of new concepts and technology. A QFD planning effort aims to maximize customer satisfaction; however, market considerations limit the number and the extent of the possible product features incorporated into a product. Hence, product designers need to know how to make tradeoffs in selecting design features, which results in the highest level of customer satisfaction [4].

Quality function deployment (QFD) is a methodology that helps translating customer needs into design requirements to ensure that the output, whether this is a product or process, meets these needs [5]. Originated in the manufacturing industry, QFD also finds applications in service industries. QFD was developed in Japan in the late 1960s as a design process aid to incorporate customer voice into a product before it was manufactured. Its success came in the form of reduction in startup costs and development time and increased quality of a new product [6]. Its applications are mostly found in design-related efforts, and many still limit QFD use to product design and development [7], [8], [9], [10], [11], [12], [13].

\section{QUALITY FUNCTION DEPLOYMENT}

QFD is a systematic process used by cross-functional teams to identify and resolve the issues involved in providing products, processes, services, and strategies that enhance customer satisfaction [14]. Akao [15] defines QFD as a method for defining design qualities to keep with customer expectations and then translate the customer requirements into design targets and critical quality assurance points that can be used throughout the production/service development phase. Gonza'lez [16] affirms that QFD has two fundamental purposes to improve: (1) the communication of customer requirements throughout the organization, and, (2) the completeness of specifications and to make them traceable directly to customer requirements and needs.

According to Heizer \& Render [17], QFD is a process for determining customer requirements (customer "wants") and translating them into the attributes (the "hows") that each functional area can understand and act on it. The idea is to capture a rich understanding of customers' wants and identify alternative process solutions. This information is then integrated into the evolving product design. QFD is used early in the design process to determine what will satisfy the customer and deploy quality efforts. One of the tools in QFD is the house of quality.

\section{House of Quality}

The house of quality is a graphic technique for defining the relationship between customer desires and product (or service) [17]. According to Suratman [18], in general, HOQ provides a powerful description, so the producers can conclude diverse information and describe the reciprocal relationships between various elements. The advantage of QFD will provide a product plan and budget details that can maximize consumers' satisfaction and earn profits for producers.

\section{Six Basic Steps}

There are six basic steps for building a house of quality [17]:

(1) Identifying the customer's wants

(2) Identifying how the good/service will satisfy customer wants.

(3) Relating customer wants to product "hows."

(4) Identifying relationships between the firm's "hows."

(5) Developing importance ratings.

(6) Evaluating competing products.

\section{RESEARCH METHOD}

A survey was employed on the regular users of batik and batik producers in Yogyakarta to obtain the information needed. A purposive sampling technique was utilized because the information needed could be obtained from one target group providing the desired information and because informants had the information needed and aligned with the researcher [19]. The subject are chosen in such a way that they reflect the diversity of the population [20].

The questionnaire was given to 85 batik users and 30 batik producers in Yogyakarta. The data were obtained 
directly from respondents through questionnaires and interviews regarding expectations and specifications from the producers' perception.

Of these 85 surveys, 50.6 percent were female, 38.8 percent were male, and $10.6 \%$ revealed no available data. The majority of respondents were 17-22 years old with the latest education in senior high school.

Table 1. Respondents' level of preference for batik

\section{QFD ANALYSIS}

\section{Respondents' Preference Level for Batik}

Before analyzing the QFD, the level of respondents' preference would be explained for batik and the origin of batik, which was the user's choice. The following is the level of preference for Batik and Batik origin.

\begin{tabular}{|l|l|l|}
\hline Level of Preference & Total & Percentage \\
\hline Very dislike & 0 & $0 \%$ \\
\hline Dislike & 3 & $3.5 \%$ \\
\hline Neutral & 34 & $40 \%$ \\
\hline Like & 40 & $47.1 \%$ \\
\hline Really like & 8 & $9.4 \%$ \\
\hline Total & $\mathbf{8 5}$ & $\mathbf{1 0 0 \%}$ \\
\hline
\end{tabular}

Source: Data processed, 2019

The majority of respondents liked batik, equal to 40 people or $47.1 \%$, and only $3.5 \%$ did not like batik. Furthermore, 34 or $40 \%$ of respondents were neutral; most respondents were young, which might have caused this. However, batik design is currently a trend and innovative so that it can reach all groups. It is expected that in the future, there will be more and more young people to like this batik.
To further analyze the batik from which regions the respondents preferred, the batik origin table is presented. The origin of batik would be strongly related to the characteristics and design of each region. In answering the preference level based on batik origin, respondents could choose more than one answer.

Table 2. Level of preference based on origin of batik

\begin{tabular}{|l|l|l|}
\hline The Origin of Batik & Total & Percentage \\
\hline Batik Yogyakarta & 47 & $55.3 \%$ \\
\hline Batik Solo & 26 & $30.6 \%$ \\
\hline Batik Pekalongan & 17 & $20 \%$ \\
\hline Batik Cirebon & 7 & $8.2 \%$ \\
\hline Others (Lasem, Mojokerto, Kalimantan, etc) & 10 & $11.8 \%$ \\
\hline
\end{tabular}

Source: Data processed, 2019

Based on Table 2, Batik Yogyakarta was the most favored because it has a classic design but is innovative in terms of natural material and design motifs. This design has made Yogyakarta batik more popular. Some respondents also mentioned other batik types, such as Lasem, Kalimantan, Mojokerto, and others, showing that Indonesia has a rich and varied culture. Almost every island in Indonesia has a Batik with its characteristics

\section{QFD Steps}

In general, the QFD implementation in the development of the special design of Batik Yogyakarta is divided into three stages:

\section{Customer's Voice Collection Stage}

At this stage, the customer's requirements were surveyed. The QFD process required consumer data as attributes of batik products. These attributes are potential benefits that consumers can receive from the product.

Based on this step, the following are the customer's voice in the form of attributes and the importance/customer importance level determined by the respondent.

Table 3. Customer Requirement and Customer Importance

\begin{tabular}{|c|l|l|}
\hline No. & Customer Requirement & Customer Importance \\
\hline 1. & Modern/trendy motif & 5 \\
\hline 2. & Young people's taste & 5 \\
\hline 3. & Classic/ethnic/ traditional design & 3 \\
\hline 4. & Abstract/contemporary motif & 3 \\
\hline 5. & Natural silk material & 5 \\
\hline 6. & Simple design & 1 \\
\hline 7. & Lurik motif & 1 \\
\hline 8. & Plant/flower motif & 3 \\
\hline
\end{tabular}




\begin{tabular}{|c|l|l|}
\hline 9. & Bright color & 5 \\
\hline 10. & Dark/inconspicuous color & 3 \\
\hline 11. & Fashionable/elegant design & 5 \\
\hline 12. & Syar'i design & 5 \\
\hline 13. & Plain combination batik & 1 \\
\hline 14. & Design characterizes the region. & 5 \\
\hline
\end{tabular}

Source: Data processed, 2019

The table shows consumers' ratings with five (high), three (medium), and one (low).

\section{House of Quality Preparation Stage}

Table 4. Technical Response
Next, the table below represents a recapitulation of the technical response obtained from interviews with the batik producers.

\begin{tabular}{|l|l|}
\hline No. & Customer Requirement \\
\hline 1. & Color Selection \\
\hline 2. & Innovative Design \\
\hline 3. & Use of natural materials \\
\hline 4. & Classic Design \\
\hline 5. & Has a characteristic \\
\hline 6. & Design follows trends \\
\hline 7. & Accentuate regional culture \\
\hline 8. & Ornamental variation \\
\hline 9. & Not violating the norm \\
\hline
\end{tabular}

Source: Data processed, 2019

The next step is to determine the correlation symbol used, the strong relationship symbolized by $\odot$, the medium relationship being represented by $\bigcirc$, and the weak relationship symbolized by $\bullet$. After determining these relationships' symbols, then arranged in the House of Quality (Fig. 1).

After completing the House of Quality, the next step is the interpretation of the results. The interpretation phase becomes essential to translate what the customer wants and what has been done by the producers.

\section{Stage of Analysis and Interpretation}

In this section, the analysis and interpretation of quality houses will be carried out in the previous stages. Moreover, suppose the company implements the output at this stage. In that case, the product will have strong characteristics to meet the consumer's desires.

The customer's attribute importance level can be seen in the importance column with the highest score of 5 . These attributes are modern/trendy motifs, young people's tastes, natural silk, bright colors, design characterizes the region, fashionable/elegant design, and plain combination batik.

Based on the relationship between technical responses, the priority of design improvement, according to the manufacturer, is Color Selection. It deals with many other technical responses, such as the Use of Natural Materials and Ornamental Variations. Then Innovative Design because it is related to the Use of Natural Materials and Ornamental Variations. The last is the Classic Design associated with Has a Characteristic, Accentuate Regional Culture and Ornamental variations.

Meanwhile, absolute importance connects the level of importance according to the customer with the technical response. The highest score in absolute importance is 215, which is on the technical response of Color Selection. The design attribute of Color Selection that the customer wants is modern/trendy motifs, young people's tastes, classic/traditional designs, abstract/ contemporary motifs, natural silk materials, simple designs, bright colors, dark/inconspicuous color, design characterizes the region and plain combination batik. The secondhighest score of 172 is characterized by the attributes of classic/traditional design, abstract/ contemporary motifs, natural silk material, lurik motifs, plant/flower motifs, designs characterizing the region, and plain combination batik. The next highest score is the decoration with a score of 152. In the manufacturer's technical response about Ornamental Variations related to attributes of modern/trendy motifs, young people's tastes, classical/traditional designs, abstract/ contemporary motifs, simple designs, plant/ flower motifs, and designs characteristics of the region. Meanwhile, the innovative design is also an option because of the high score of 140 The technical response is related to modern/trendy motifs, young people's tastes, and abstract/contemporary motifs.

Based on customers' and producers' preferences, both had the same perception that a special Yogyakarta Batik design must be developed. It was because Yogyakarta has a strong Javanese culture. Coupled with the Yogyakarta Palace that still exists today, it adds to Yogyakarta batik's strong characteristic, which is full of meaning. The 
competitors of Yogyakarta Batik, namely Solo Batik and Pekalongan Batik, also have Solo and Pekalongan Palace. However, the Palace's existence did not affect people's daily life and tastes towards batik. Moreover, Pekalongan palace is no longer active.

Competitor analysis in the House of Quality matrix included two competitors, Batik Solo and Batik Pekalongan, considered potential competitors of Batik Yogyakarta. Judging from the criteria for customers' attributes, the competitor with the highest qualification was Batik Pekalongan with good qualifications for seven attributes, fair for five attributes, and poor condition for two attributes. It can be interpreted that Yogyakarta Batik must make improvements to the design quality in accordance with customers' wishes because competitors could meet $50 \%$ of the customer attributes. More detail can be seen in Fig. 1 .

Based on these results, it could be concluded that the batik design satisfying customer desires was the choice of colors that varied according to customer tastes, such as bright colors, dark colors/inconspicuous, and natural coloring. Besides, the desired batik design was batik, which could combine classical batik motifs with modern designs and follow young people's wishes.

Another thing that needed to be observed was the syar'i design, meaning that batik motifs in accordance with the Islamic Shari'a. There are two possibilities: syar'i, in terms of motives/images using images that do not contain SARA (ethnicity, religion, race, and intergroup) and pornographic elements. The second is syar'i in terms of fashion that covers aurat and is not tight. Concerning these results, batik producers should fulfill this desire. Some batik producers in Yogyakarta usually sold ready-made batik (already in the form of ready-made clothing), so manufacturers could make sure that fashion designs were made according to religious rules.

The development of batik design that suited the customer's desires referred to the elements relating to the selection of colors special of Yogyakarta and the combination of modern and classical elements. The innovative design using natural coloring is now preferred because it is environmentally friendly, and the colors are more exclusive.

Based on the competitor of Yogyakarta Batik: Batik Solo, and Batik Pekalongan, it was concluded that Batik Pekalongan was more potential as a competitor because it had the superior ability in fulfilling customer attributes. As many as $50 \%$ of attributes or seven attributes had a good qualification. Batik Yogyakarta must concern this result to be superior and have distinctive characteristics that differentiate it from competitors.

\section{CONCLUSION AND RECOMMENDATION}

This paper's results indicated that the main attributes that customers wanted for a special Yogyakarta batik design included modern/trendy motifs, young people's tastes, natural silk materials, bright colors, distinctive regional designs, fashionable/elegant designs, and plain combination batik. Based on the relationship between technical responses, the priorities of design improvement, according to the manufacturer, were color selection, innovative design, and classical design. It deals with many other technical responses, meaning that the improvement in these three means also increases other technical response preferences.

Based on the absolute importance, producers' main priority to fulfill customer desires and satisfaction was the selection of colors. The customer's desired design attributes included a modern/trendy design, young people's tastes, classic/traditional designs, abstract/ contemporary motifs, natural silk materials, simple designs, bright colors, dark/inconspicuous colors, distinctive regional designs, and plain combination batik. Judging from the criteria on customers' attributes, the competitor with the highest qualification was Batik Pekalongan because it had more good qualifications than Batik Solo. Thus, Batik Yogyakarta must improve the design quality according to customer desires because competitors have fulfilled $50 \%$ of the customer's attributes.

Therefore, the following are several recommendations for special batik designs in Yogyakarta.

(1) Batik Yogyakarta must make improvements to the design quality in accordance with the customer wants to achieve satisfaction. By referring to the House of Quality results, color selection is a priority because Batik design has the power to color, especially natural coloring, which shows the distinctive characteristics of each region.

(2) Yogyakarta Batik must always innovate designs to meet young people's tastes and combine classical and modern elements to reach all groups.

(3) Disperindagkop (Department of Industry, Trade, Cooperatives and SMEs) facilitates the development activities of small and medium industries to innovate and enhance creativity so that SME products can compete at the international level.

(4) Further research needs to increase the number of respondents to be more representative. 


\section{ACKNOWLEDGMENTS}

We would like to thank Universitas Muhammadiyah Yogyakarta, especially The Institute for Research, Publication and Community Service (LP3M) so that we could carry out this research.

\section{REFERENCES}

[1] E.S. Hamid, Y.S. Susilo. Strategi Pengembangan Usaha Mikro Kecil dan Menengah di Provinsi Daerah Istimewa Yogyakarta, Jurnal Ekonomi Pembangunan, 2011, Vol. 12, No. 1, p.45-55.

[2] N. Mafazah, H. Sujoko. Penerapan Metode Quality Function Deployment (QFD) untuk Pengembangan Desain Motif Batik Khas Kalimantan Timur, J@TI, Undip, 2014,Vol. IX, No 2.

[3] N. Yulianti, I.A. Soenandi. Usaha Peningkatan Pelayanan PT. X Supermarket dengan Metode Fuzzy Quality Function Deployment (QFD)“, Jurnal Ilmiah Teknik Industri, 2014, Vol. 2, No. 1, 21-27.

[4] G.S. Wasserman. On how to prioritize design requirements during the QFD planning process, IIE Transactions, 1993, Vol. 25 (3), 59-65.

[5] N.O. Erdil, O.M. Arani. Quality function deployment: more than a design tool, International Journal of Quality and Service Sciences, 2018, Vol. 11(1) DOI: $10.1108 /$ IJQSS-02-2018-0008

[6] R.J. Evans, M.W. Lindsay. An Introduction to Six Sigma \& Process Improvement, Cengage Learning, 2nd ed., Stamford, CT. 2015.

[7] F. Franceschini. Advanced Quality Function Deployment, 6CRC Press, Boca Raton, Florida, 2002.

[8] I. Breyfogle, W. Forrext. Implementing Six Sigma: Smarter Solutions Using Statistical Methods, 6th ed, Wiley \& Sons, Inc., Hoboken, New Jersey, 2003.

[9] L.C. Cheng, QFD in product development: methodological characteristics and a guide for intervention, International Journal of Quality \& Reliability Management, 2003, Vol. 20 No. 1, pp. 107-122.
[10] National Academy of Engineering and Institute of Medicine. Building a Better Delivery System: A New Engineering/Health Care Partnership, National Academies Press, 2005.

[11] G. Herzwurum, S. Schockert. What are the best practices of QFD? Proceedings of the 12th International Symposium on Quality Function Deployment, Tokyo, 2006.

[12] P.A.C. Miguel. Innovative new product development: a study of selected QFD case studies, The TQM Magazine, 2007, Vol. 19 No. 6, pp. $617-$ 625.

[13] A. Mitra. Fundamentals of Quality Control and Improvement, 4th ed., John Wiley \& Sons, Inc., Hoboken, New Jersey, 2016.

[14] M. Gonza'lez, Q. Quesada, T. Bahill. Improving product design using quality function deployment: the school furniture case in developing countries, Quality Engineering Journal, 2003, Vol. 16 No. 1, pp. 47-58.

[15] Y. Akao. QFD: Integrating Customer Requirement into Product Design, Productivity Press, Cambridge. Massachusetts. 1990.

[16] M. Gonza'lez. Quality Function Deployment; A Road for Listening the Customer Expectations, McGraw-Hill Mexico City, Mexico, 2001.

[17] Heizer, B. Render, C. Munson. Operation Management, International Edition, Pearson Education, Inc., New Jersey, 2017.

[18] A. Suratman. The Application of Quality Function Deployment (QFD) for Quality of Indoor Rattan Chairs' Product Design for European Market, Proceeding Seminar Nasional dan Call For Papers Sancall, 2013.

[19] A. Ferdinand. Metode Penelitian Manajemen, $4^{\text {th }}$ ed, Badan Penerbit Universitas Diponegoro, Semarang, 2013.

[20] U. Sekaran, R. Bougie. Research Methods for Business, John Wiley \& Son Ltd., United Kingdom, 2009. 


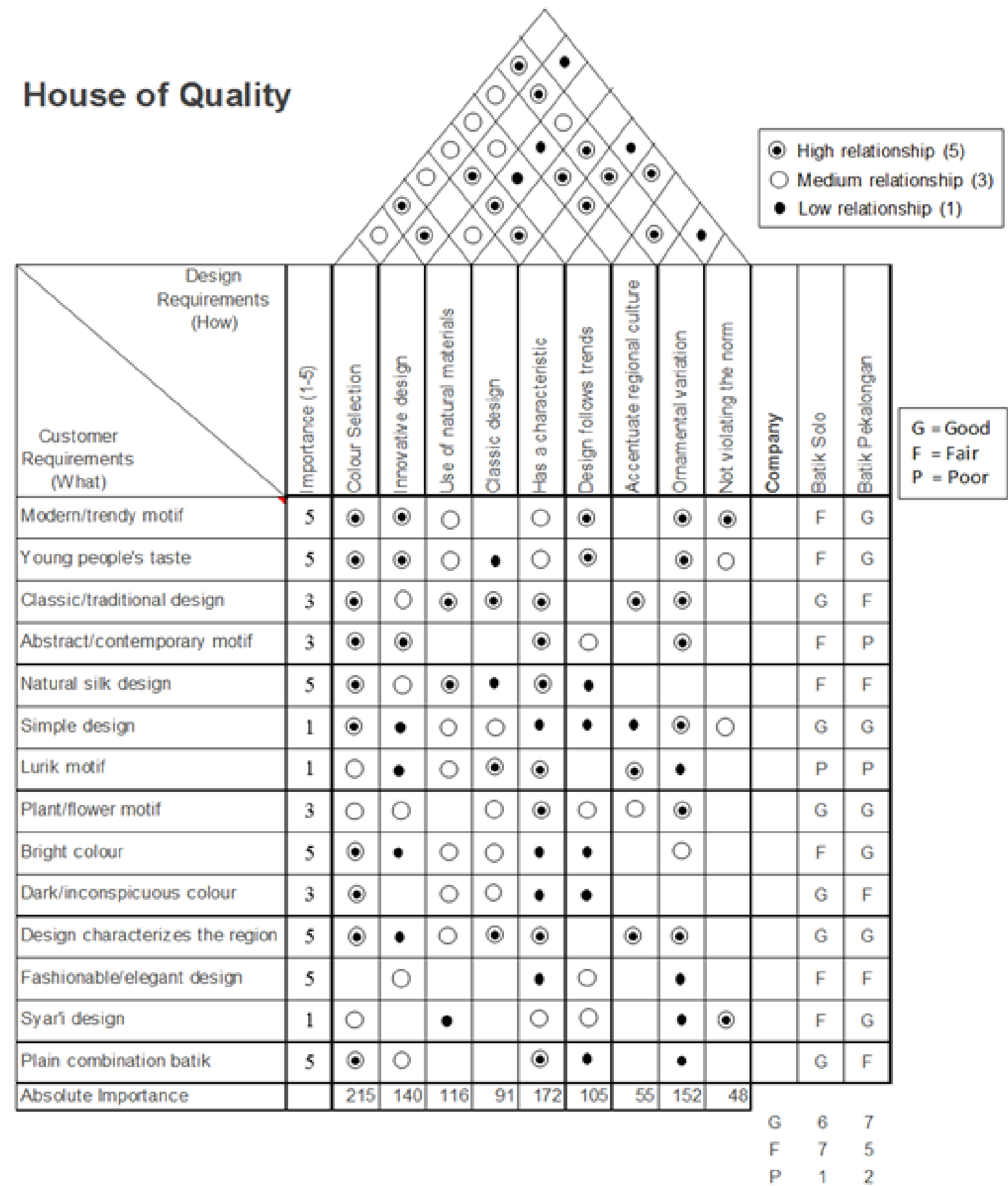

Figure 1 Caption content. The title "Figure" and the label should be in bold. 